\title{
Analisis Kurikulum Mata Pelajaran Al-Qur'an Hadis Madrasah Aliyah
}

\author{
Tatik Fitriyani ${ }^{1}$, Iman Saifullah ${ }^{2}$ \\ Program Magister Pendidikan Agama Islam IAIN Syekh Nurjati Cirebon \\ tykfit@gmail.com
}

\begin{abstract}
Abstrak
Penelitian ini bertujuan untuk mendeskripsikan prosentase komponen kompetensi serta analisis materi dalam Kurikulum mata Pelajaran AlQuran Hadis di tingkat Madrasah Aliyah dilihat dari beberapa perspektif, diantaranya perspektif psikologi perkembangan dan konsep Pendidikan Islam Sosial Profetik Kuntowijoyo. Penelitian ini merupakan penelitian kualitatif deskriptif analitik dengan pengumpulan data menggunakan metode dokumentasi. Kesimpulan dari penelitian ini adalah bahwa muatan kompetensi pada kurikulum Al-Quran Hadis di MA pada aspek kompetensi afektif spirirtual (KI-1) berada pada tahap Karakterisasi (A5) sebanyak 90\%, kompetensi afektif sosial (KI-2) berada pada level karakterisasi dengan prosentasi $100 \%$, kompetensi kognitif nya (KI-3) berada pada level menganalisis (C4) dengan total prosentase 97\%, dan kompetensi psikomotor (KI-4) 63\%. Sedangkan materi yang sesuai dengan konsep Sosial Profetik Kuntowijoyo diantaranya adalah materi menjaga kelestarian lingkungan hidup dan materi Manusia serta tugasnya sebagai Khalifah Fil ard'.
\end{abstract}

Keywords : Kurikulum Al-Qur'an Hadis, Madrasah Aliyah

\section{Pendahuluan}

Lembaga pendidikan Islam termasuk didalamnya Madrasah Aliyah adalah sarana yang dianggap mampu mentransformasikan nilai-nilai agama pada masyarakat yang terus mengalami perkembangan. Didalamnya diajarkan materi-materi pendidikan agama islam salah satunya yaitu materi Al -Qur'an Hadits sebagai sumber hukum dan pegangan hidup umat Islam. Pembelajaran Al Qur'an Hadits sangatlah penting bagi umat islam umumnya dan siswa sekolah khususnya. Sehingga, materi AlQur'an Hadits mestinya terus dikembangkan dan digali baik dalam hal pemahaman maupun pengamalannya. Sebab pembelajaran Al- Qur' an Hadits menjadi salah satu aspek penentu keberhasilan tercapainya tujuan pembelajaran nasional serta pembelajaran Islam. 
Salah satu aspek yang mempengaruhi keberhasilan pembelajaran nasional yaitu aspek kurikulum. Karena kurikulum merupakan salah satu komponen yang memiliki peranan berarti dalam sistem pembelajaran. Dalam Undang- Undang No 20 Tahun 2003 tentang Sistem Pembelajaran Nasional, dijelaskan bahwa kurikulum ialah seperangkat perencanaan serta pengaturan yang memuat tujuan, isi, serta bahan pelajaran dan metode yang digunakan sebagai acuan penyelenggaraan aktivitas pendidikanagar tercapai tujuan pembelajaran tertentu. Bersumber pada penafsiran tersebut, terdapat 2 ukuran kurikulum, yang pertama ialah perencanaan serta pengaturan mengenai tujuan, isi, serta bahan pendidikan. Kedua yaitu metode yang digunakan buat penyelenggaraan pendidikan (KMA, 2019:13).

Kurikulum Al-Qur'an Hadis sebegai salah satu mata pelajaran di Madrasah Aliyah tentunya menjadi acuan formal pendidik dan siswa dalam menciptakan pengalaman belajar di kelas (in class) atau di luar kelas ( out class) yang di dalamnya berisi berbagai macam Kompetensi Dasar( KD) gunatercapai Kompetensi Inti( KI) untuk mewujudkan Kompetensi Lulusan( KL) pada jenjang Madrasah Aliyah melalui kurikulum Al- Qur' an serta Al- Hadits.

Al- Qur' an Hadis dalam perspektif kurikulum 2013 masuk dalam kelompok mata pelajaran Pembelajaran Agama Islam serta Bahasa Arab. Mata pelajaran Al- Qur' an Hadis ialah satu di antara bermacam-macam disiplin ilmu yang mengemban amanah Undang- Undang SISDIKNAS No 20 Tahun 2003 Pasal 1 serta 3, dan Permenag No 912 Tahun 2013 yang core value nya merupakan nilai spiritualitas serta sosial, ialah iman, takwa, serta akhlak mulia. Pentingnya menekuni serta mengamalkan Al- Qur' anHadits tentu agar tercipta manusia- manusia yang berkepribadian muslim. Individu muslim merupakan individu yang dibangun melalui penanaman nilai- nilai yang bersumber dari Al- Qur' an Hadits. Secara substansial, mata pelajaraan Al Qur'an Hadits memilki kontribusi untuk mentransformasikan nilai-nilai agama sebagai sumber utama ajaran Islam dan sekaligus menjadi pegangan dan pedoman hidup dalam kehidupan sehari-hari (Peraturan Menteri Agama RI Nomor 2 Tahun 2008 :132).

Pendidikan Islam terutama mata pelajaran Al-Quran Hadis sebagai sumber ajaran islam dibutuhkan eksistensinya di kehidupan masyarakat karena pengaruh globalisasi dan moderenisasi. Mata pelajaran Al-Quran Hadis dituntut mampu mentransformasikan nilai-nilai normatif ke dalam kehidupan masyarakat sehingga pelajaran agama yang bersumber pada alQuran Hadis tidak hanya dipersepsikan oleh masyarakat Muslim sebagai pendidikan transenden atau pendidikan yang hanya sibuk memperkuat spiritual tanpa menyinggung permasalahan social (Kuntowijoyo, Muslim Tanpa Masjid, 2010:357-358). Selain itu merosotnya moralitas yang ada di kalangan pelajarpun seringkali menimbulkan pertanyaan akan fungsi dari pelajaran agama dilembaga pendidikan islam. Hal ini berdasar atas fenomena yang terjadi saat ini bahwa pembelajaran agama baru sampai dan lebih banyak ditekankan pada aspek kognitif daripada aspek apektif yang terealisasi dalam pembentukan sikap peserta didik. Sehingga eksisitensi pelajaran agama terus menerus di pertanyakan. Oleh 
karena itu, banyak cendekiawan Muslim yang memformulasikan agar eksistensi nilai-nilai Islam yang luhur tidak luntur dan tetap berbekas dalam kehidupan masyarakat dan tertanam sejak dini. Diantara banyak cendekiawan Muslim, Kuntowijoyo melahirkan ide serta gagasan cemerlang yang terangkum dalam sebuah paradigma Islam berbasis social profetik. Ide serta gagasan tokoh tersebut dapat memberikan implikasi terhadap pengembangan kurikulum pendidikan Islam termasuk mapel Al-Qur'an Hadis jenjang MA di masa yang penuh tantangan. Berdasarkan latar belakang tersebut, maka masalah dalam penelitian ini yaitu 1 . Berapa besar prosentase kompetensi dan bagaimana analisis kompetensi di lihat dari perkembangan psikologi peserta didik? 2. Bagaimana analisis materi Kurikulum Mata Pelajaran Al-Quran Hadits Madrasah Aliyah perspektif sosial profetik Kuntowijoyo?

\section{Metodologi}

Jenis penelitian ini penelitian kepustakaan (Library research)menggunakan pendekatan kualitatif deskriptif. Pengumpulan data menggunakan metode dokumentasi yaitu mengumpulkan dokumen-dokumen terkait kurikulum PAI di Madrasah Aliyah.

\section{Hasil dan Pembahasan}

\subsection{Analisis Kompetensi Kurikulum Al-Quran Hadis Madrasah Aliyah}

Pembelajaran Al Qur'an Hadis di Madrasah Aliyah bertujuan memberikan bekal kepada peserta didik untuk memahami ayat-ayat Al-Qur'an dan Hadits nabi sebagai sumber utama ajaran Agama Islam. Bahkan kajiannya mencakup pengetahuan tentang Ulumul Qur'an, ilmu Hadits, dan ayat-ayat serta hadits-hadits pilihan. Kurikulum 2013 menyebutkan beberapa komponen yang berkaitan dengan mata pelajaran Al-Qur'an-Hadis pada Madrasah Aliyah yang mencakup tujuan dan ruang lingkup materi, sebagai berikut:

\section{Tujuan}

Mata pelajaran Qur'an-Hadis bertujuan untuk: a) Meningkatkan kecintaan peserta didik terhadap al-Qur'an dan Hadis, b) Membekali peserta didik dengan dalil-dalil yang terdapat dalam al-Qur'an dan Hadis sebagai pedoman dalam menyikapi dan menghadapi kehidupan, c) Meningkatkan pemahaman dan pengamalan isi kandungan al-Qur'an dan al-Hadis yang dilandasi oleh dasar-dasar keilmuan tentang al-Qur'an dan al-Hadis (KMA, 2019:13).

Sementara Ruang Lingkup materi Al Qur'an Hadis pada Madrasah Aliyah mencakup (KMA, 2019:13):

a. Masalah dasar-dasar ilmu al-Qur'an meliputi:

1) Al- Qur'an dan wahyu menurut para ulama',

2) Sejarah penurunan dan penulisan Al-Qur'an,

3) Bukti-bukti keautentikan Al-Qur'an,

4) Kemukjizatan Al-Qur'an,

5) Pokok-pokok isi Al-Qur'an, 
6) Struktur ayat dan surat dalam Al-Qur'an.

b. Dasar-dasar ilmu al-hadits meliputi:

1) Perihal hadis, sunah, khabar dan atsar (macam-macam sunnah),

2) Perkembangan hadis,

3) Unsur-unsur hadis,

4) Fungsi hadis terhadap al-qur'an,

5) Pembagian hadis dari segi kuantitas dan pembagian hadis dari segi kualitasnya,

6) Biografi tokoh-tokoh hadis dan kitabnya.

c. Tema-tema yang ditinjau dari perspektif al-Qur'an dan Hadis, yaitu (KMA, 2019:13):

1) Manusia dan tugasnya sebagai khalifah di bumi,

2) Demokrasi dan musyawarah mufakat,

3) Keikhlasan dalam beribadah,

4) Nikmat Allah dan cara mensyukurinya,

5) Perintah menjaga kelestarian lingkungan hidup,

6) Pola hidup sederhana dan perintah menyantuni para dhuafa,

7) Berkompetisi dalam kebaikan,

8) Amar ma'ruf nahi munkar,

9) Ujian dan cobaan manusia,

10) Tanggung jawab manusia terhadap keluarga dan masyarakat,

11) Berlaku adil dan jujur,

12) Toleransi dan etika pergaulan,

13) Etos kerja,

14) Makanan yang halal dan baik,

15) Ilmu pengetahuan dan teknologi.

Tujuan dan ruang lingkup materi-materi yang telah ditetapkan dalam kurikulum 2013 selanjutnya dikembangkan dalam pengalaman belajar di sekolah yang didahului dengan langkah pembuatan desain pembelajaran yang tertuang dalam silabus, Rencana Pelaksanaan Pembelajaran (RPP), buku pegangan guru, dan buku pegangan peserta didik yang memuat tentang komponen-komponen kurikulum mata pelajaran Al-Qur'an Hadis yang mengacu pada standar kelulusan dan standar isi (KMA, 2019:13).

Adapun Standar Kompetensi Lulusan Madrasah Aliyah yaitu :

Tabel 1

Standar Kompetensi Lulusan Madrasah Aliyah Madrasah Aliyah Kualifikasi Kemampuan 


\begin{tabular}{|c|c|}
\hline Sikap & $\begin{array}{l}\text { Memiliki perilaku yang mencerminkan } \\
\text { sikap: beriman dan bertakwa kepada } \\
\text { Tuhan YME, berkarakter, jujur, dan } \\
\text { peduli, bertanggungjawab, pembelajar } \\
\text { sejati sepanjang hayat, serta sehat } \\
\text { jasmani dan rohani, sesuai dengan } \\
\text { perkembangan anak di lingkungan } \\
\text { keluarga, madrasah, masyarakat dan } \\
\text { lingkungan alam sekitar, bangsa, } \\
\text { negara, kawasan regional, dan } \\
\text { internasional. }\end{array}$ \\
\hline Pengetahuan & $\begin{array}{l}\text { Memiliki pengetahuan faktual, } \\
\text { konseptual, prosedural, dan } \\
\text { metakognitif pada tingkat teknis, } \\
\text { spesifik, detil, dan kompleks berkenaan } \\
\text { dengan: ilmu pengetahuan, teknologi, } \\
\text { seni, budaya, dan humaniora. Mampu } \\
\text { mengaitkan pengetahuan di atas dalam } \\
\text { konteks din sendiri, keluarga, } \\
\text { madrasah, masyarakat dan lingkungan } \\
\text { alam sekitar, bangsa, negara, serta } \\
\text { kawasan regional dan internasional. }\end{array}$ \\
\hline Keterampilan & $\begin{array}{l}\text { Memiliki keterampilan berpikir dan } \\
\text { bertindak: kreatif, produktif, kritis, } \\
\text { mandiri, kolaboratif, dan komunikatif } \\
\text { melalui pendekatan ilmiah sebagai } \\
\text { pengembangan dari yang dipelajari di } \\
\text { satuan pendidikan dan sumber lain } \\
\text { secara mandiri. }\end{array}$ \\
\hline
\end{tabular}

Kurikulum 2013 merupakan kurikulum baru yang mulai di terapkan pada tahun pelajaran 2013/2014. Kurikulum ini adalah pengembangan dari kurikulum yang telah ada sebelumnya, baik kurikulum berbasis kompetensi yang telah di rintis pada tahun 2004 maupun kurikulum tingkat satuanpendidikan pada tahun 2006. Hanya saja yang menjadi titik tekan pada kurikulum 2013 ini adalah adanya peningkatan dan keseimbangan soft skill dan hard skill yang meliputi aspek kompetensi sikap, ketrampilan, dan pengetahuan (Fadillah, 2014 :16).

Adapun struktur kurikulum Madrasah Aliyah meliputi, Kompetensi Inti, kompetensi dasar dan lain sebagainya. Dalam kurikulum 2013 kompetensi ini mencakup beberapa aspek yaitu sikap spritual (KI-1), sikap sosial (KI-2), pengetahuan (KI-3) dan keter ampilan (KI-4) yang berfungsi sebagai pengintegrasi muatan pembelajaran, mata pelajaran, atau program dalam mencapai standar kompetensi lulusan (Mulyasa, 2014: 65)

Kompetensi inti mata pelajaran Al-Qur'an Hadis adalah sebagai berikut. 
Tabel 2

Kompetensi Inti Al-Qur'an Hadis Madrasah Aliyah kelas X-XII

\begin{tabular}{|c|c|c|c|}
\hline \multicolumn{4}{|c|}{ Kompetensi Inti Kelas X-XII } \\
\hline $\begin{array}{l}\text { Menghayati dan } \\
\text { mengamalkan } \\
\text { ajaran agama } \\
\text { yang dianutnya }\end{array}$ & $\begin{array}{l}\text { Menghayati dan } \\
\text { mengamalkan } \\
\text { perilaku jujur, } \\
\text { disiplin, } \\
\text { tanggungjawab, } \\
\text { peduli (gotong } \\
\text { royong, } \\
\text { kerjasama, } \\
\text { toleran, damai), } \\
\text { santun, responsif } \\
\text { dan pro-aktif dan } \\
\text { menunjukkan } \\
\text { sikap sebagai } \\
\text { bagian dari solusi } \\
\text { atas berbagai } \\
\text { permasalahan } \\
\text { dalam sam } \\
\text { berinteraksi } \\
\text { secara efektif } \\
\text { dengan sosial } \\
\text { lingkungan son } \\
\text { dan alam serta } \\
\text { dalam menempatkan diri } \\
\text { sebagai cerminan } \\
\text { bangsa dalam } \\
\text { pergaulan dunia. }\end{array}$ & $\begin{array}{l}\text { Memahami,menerapkan, } \\
\text { dan menganalisis } \\
\text { pengetahuan faktual, } \\
\text { konseptual, prosedural } \\
\text { berdasarkan rasa } \\
\text { ingintahunya tentang } \\
\text { ilmu pengetahuan, } \\
\text { teknologi, seni, budaya, } \\
\text { dan humaniora dengan } \\
\text { wawasan kemanusiaan, } \\
\text { kebangsaan, } \\
\text { kenegaraan, } \\
\text { peradaban dan } \\
\text { penyebab fenomena dan } \\
\text { kejadian, serta } \\
\text { menerapkan } \\
\text { pengetahuan prosedural } \\
\text { pada bidang kajian yang } \\
\text { spesifik sesuai dengan } \\
\text { bakat dan minatnya } \\
\text { untuk memecahkan } \\
\text { masalah }\end{array}$ & $\begin{array}{l}\text { Mengolah, } \\
\text { menalar, dan } \\
\text { menyaji dalam } \\
\text { ranah konkret } \\
\text { dan ranah abstrak } \\
\text { terkait dengan } \\
\text { pengembangan } \\
\text { dari yang } \\
\text { dipelajarinya di } \\
\text { madrasah secara } \\
\text { mandiri, dan } \\
\text { mampu } \\
\text { menggunakan } \\
\text { metode sesuai } \\
\text { kaidah keilmuan }\end{array}$ \\
\hline
\end{tabular}

Berdasarkan tabel di atas dapat dilihat bahwa kompetensi Inti Al-Qur'an Hadis di Madrasah Aliyah sudah sesuai dengan karakteristik PAI yang mengembangkan keseimbangan hidup baik spiritual maupun sosial, pengetahuan dan keterampilan yang pada akhirnya dapat di realisasikan dalam kehidupan sehari-hari. Sehingga nilai-nilai agama diharapkan benar-benar terinternalisasi dalam diri peserta didik baik dalam cara berfikir, bertindak maupun bersikap.

Selanjutnya, mengenai kompetensi dasar. Kompetensi dasar adalah kemampuan untuk mencapai kompetensi inti yang harus diperoleh peserta didik melalui pembelajaran. Kompetensi dasar merupakan gambaran pokok materi yang harus disampaikan kepada peserta didik. Dalam PP Nomor.32 Tahun 2013 bahwa 
kompetensi dasar ialah tingkat kemampuan dalam konteks muatan pembelajaran, pengalaman belajar, atau mata pelajaran yang mengacu pada kompetensi inti (Iqbal Faza, Sukiman, 2019: 138).

Analisis kompetensi dasar ini tidak akan terlepas dari konsep pembelajaran keterampilan Berpikir Tingkat Tinggi yang dalam bahasa umum dikenal sebagai Higher Order Thinking Skill (HOTS). Menurut Domin contoh implementasi HOTS adalah pada sikap berpendapat, mengambil kesimpulan, merencanakan, dan menilai. Keterampilan ini juga digunakan untuk menggarisbawahi berbagai proses tingkat tinggi menurut jenjang taksonomi Bloom (Elizabeth, 2017:12).

Menurut Bloom (Anderson, 2010:46) keterampilan dibagi menjadi dua bagian. Pertama adalah keterampilan tingkat rendah yang penting dalam proses pembelajaran,yaitu mengingat (remembering), memahami (understanding), dan menerapkan (applying), dan keduaadalah yang diklasifikasikan ke dalam keterampilan berpikir tingkat tinggi berupa keterampilan menganalisis (analysing), mengevaluasi (evaluating), dan mencipta (creating). Tingkatan tersebut menunjukkan bahwa berpikir untuk mengetahui merupakan tingkatan berpikir yang paling rendah (Lowerer) sedangkan menilai merupakan tingkatan berpikir paling tinggi (Higherer).

Keterampilan berpikir tingkat tinggi erat kaitannya dengan keterampilan berpikir sesuai dengan ranah kognitif, afektif, dan psikomotor yang menjadi satu kesatuan dalam proses belajar dan mengajar.

\section{a) Ranah Kognitif}

Kompetensi kognitif Al-Qur'an Hadis di MA dalam Keputusan Menteri Agama (KMA) Nomor 183 Tahun 2019 tentang Kurikulum PAI dan Bahasa Arab dihasilkan prosentase Kompetensi Ranah Kognitif Al-Quran Hadis Madrasah Aliyah sebagai berikut.

Tabel 3

Prosentase Kompetensi Ranah Kognitif

\begin{tabular}{|l|l|l|l|l|l|l|l|}
\hline \multirow{2}{*}{ No } & \multirow{2}{*}{ Kompetensi } & \multicolumn{2}{|l|}{ Kelas X } & \multicolumn{2}{l|}{ Kelas XI } & \multicolumn{2}{l|}{ Kelas XII } \\
\cline { 3 - 9 } & & Jumlah & $\%$ & Jumlah & $\%$ & Jumlah & $\%$ \\
\hline 1. & Mengidentifikasi & & & & & & \\
\hline 2. & Memahami & & & & & & \\
\hline 3. & Menerapkan & & & & & & \\
\hline 4. & Menganalisis & 11 & $92 \%$ & 10 & $100 \%$ & 8 & $100 \%$ \\
\hline 5. & Mengevaluasi & 1 & $8 \%$ & & & & \\
\hline 6. & Mencipta & & & & & & \\
\hline
\end{tabular}

Dari tabel diatas,dapat disimpulkan jika dikalkulasikan maka proses kognitif mata pelajaran Al-Qur'an Hadis Madrasah Aliyah ini berada pada level keterampilan berfikir tinggi atau HOTS pada kompetensi menganalisis (C4) dengan total prosentase 97\% dan kompetensi mengevaluasi (C5) sebanyak 3\%. 
Jika dikaitkan dengan perkembangan psikologis peserta didik, maka pada usia Madrasah Aliyah perkembangan kognitif berkaitan dengan perkembangan berpikir yang mencakup kemampuan mengingat, sampai dengan kemampuan memecahkan suatu masalah. Menurut Pieget, sebagian besar anak usia MA mampu memahami konsep-konsep abstrak dalam batas-batas tertentu (berpikir operasional formal) (Syamsu Yusuf, 2017:27). Hal ini mengandung arti bahwa remaja awal termasuk dalam tahap operasional formal di mana mereka mampu menerima dan mengolah informasi abstrak dari lingkunganya dan telah dapat menilai benar atau salahnya pendapat-pendapat orangtua atau orang dewasa lainnya. Pada tahap ini pula siswa mampu membayangkan situasi rekaan, kejadian yang hanya berupa hipotesis ataupun proposisi abstrak, dan mencoba mengolahnya denga pemikiran logis. Bahkan siswa mampu melakukan penalaran secara deduktif dan menerapkan logika untuk membuat kesimpulan (Latifah Nur Ahyani, 2018:89).

Dilihat dari Kompetensi dasar yang telah dilampirkan, bahwa kurikulum Al-Qur'an Hadis banyak mendorong peserta didik untuk melakukan analisa pada materimaterinya. Hal ini menurut penulis sesuai dengan perkembangan kognitif peserta didik pada usia Madrasah Aliyah yang memiliki kemampuan berfikir operasional formal (Fatimah Ibda, 2015). Dengan banyaknya menganalisa maka kemampuan berfikir operasional formal terus diasah dan di maksimalkan.Dalam tahap perkembangan inipun peserta didik secara alamiah menjadi makhluk yang serba ingin tahu, maka diperbanyaknya analisis dalam pembelajaranpun untuk memenuhi rasa ingin tahu yang lebih dari peserta didik pada jenjang Madrasah Aliyah.

Namun menurut penulis, alangkah lebih baik jika kompetensi menganalisis ini diimbangi dengan kompetensi mengevaluasi, agar siswa dapat mempertimbangkan dan menilai hasil analisisnya. Hal ini nantinya akan berpengaruh pada kehidupannya dalam menilai dan mengevaluasi permasalahan dan cara dirinya memecahkan permasalahan serta mampu menningkatkan kesadaran serta kewaspadaan dalam berbagai hal.

Dengan proses kognitif pada level kompetensi evaluasi yang hanya berjumlah 1 maka menurut penulis pengetahuan metakognitif yaitu pengetahuan mengenai kesadaran secara umum sama halnya dengan kewaspadaan dan pengetahuan tentang kesadaran pribadi seseorang. Penekanan kepada peserta didik untuk lebih sadar dan bertanggung jawab untuk pengetahuan dan pemikiran mereka sendiri akan sulit dicapai.Pengetahuan metakognitif ini terdapat pada SKL MA pada dimensi kognitif, namun tidak terjabarkan dalm KI yang hanya mencantumkan pengetahuan faktual, konseptual dan prosedural.

\section{b) Ranah Afektif}

Kartwohl \& Bloom (Yoki Ariyana,dkk,, 2018:10)menjelaskan bahwa selain kognitif, terdapat ranah afektif yang berhubungan dengan sikap, nilai, perasaan, emosi serta derajat penerimaan atau penolakan suatu objek dalam kegiatan 
pembelajaran dan membagi ranah afektif menjadi 5 kategori, dari mulai penerimaan (A1), Menanggapi (A2), Penilaina (A3), Mengelola (A4), Karakterisasi (A5).

Tabel 4

Prosentase Ranah Afektif (Spiritual) Al-Qur'an Hadis MA

\begin{tabular}{|l|l|l|l|l|l|l|l|}
\hline \multirow{2}{*}{ No } & \multirow{2}{*}{ Kompetensi } & \multicolumn{3}{|c|}{ Kelas X } & \multicolumn{2}{l|}{ Kelas XI } & \multicolumn{2}{l|}{ Kelas XII } \\
\cline { 3 - 8 } & & Jumlah & $\%$ & Jumlah & $\%$ & Jumlah & $\%$ \\
\hline 1. & Menerima & 1 & $8 \%$ & & & & \\
\hline 2. & Menanggapi & & & & & & \\
\hline 3. & Menghargai & 2 & $17 \%$ & & & & \\
\hline 4. & Mengelola & & & & & & \\
\hline 5. & Karakterisasi & 9 & $75 \%$ & 10 & $100 \%$ & 8 & $100 \%$ \\
\hline
\end{tabular}

Jika dikalkulasikan table diatas menunjukkan proses afektif mata pelajaran AlQur'an Hadis yang didominasi level karakterisasi (A5) sebanyak 90\%. Dilihat kesesuainnya dengan SKL pada dimensi sikap tepatnya pada poin beriman dan bertakwa kepada Tuhan YME terjabar dalam KI 1 yaitu Menghayati dan mengamalkan ajaran agama yang dianutnya maka kurikulum mapel Al-Qur'an Hadis dengan kompetensi pada level karakterisasi (A5) ini dapat mencapai standar yang telah dirumuskan dalam SKL. Dan jika dilihat kesesuaiannya dengan KI maka pengembangan KD ini sudah sesuai dengan KI. Sedangkan ranah afektif (social) dihasilkan prosentase sebagai berikut.

Tabel 5

Prosentasi Ranah Afektif (Sosial) Al-Qur'an Hadis MA

\begin{tabular}{|l|l|l|l|l|l|l|l|}
\hline \multirow{2}{*}{ No } & \multirow{2}{*}{$\begin{array}{l}\text { Kom } \\
\text { petensi }\end{array}$} & \multicolumn{2}{l|}{ Kelas X } & \multicolumn{2}{l|}{ Kelas XI } & \multicolumn{2}{l|}{ Kelas XII } \\
\cline { 3 - 8 } & Jumlah & $\%$ & Jumlah & $\%$ & Jumlah & $\%$ \\
\hline 1. & Menerima & & & & & & \\
\hline 2. & Menanggapi & & & & & & \\
\hline 3. & Menghargai & & & & & & \\
\hline 4. & Mengelola & & & & & & \\
\hline 5. & Karakterisasi & 12 & $100 \%$ & 10 & $100 \%$ & 8 & $100 \%$ \\
\hline
\end{tabular}

Pada tabel tersebut terlihat bahwa kompetensi afektif mata pelajaran al-Qur'an Hadis dari mulai kelas X sampai kelas XII berada pada level karakterisasi dengan prosentasi $100 \%$. Seperti halnya pada ranah afektif (spiritual) jika dilihat kesesuaiannya dengan SKL maka ranah afektif (sosial) pun pada dimensi sikap tepatnya pada poin bersikap jujur dan bertanggung jawab, dst. Yang kemudian terjabar pada KI, maka KD dengan prosentasi pada level karakterisasi ini menurut penulis dapat mencapai SKL yang telah dirumuskan.

Dilihat dari perkembangan psikologis, maka siswa MA dalam perkembangan afektifnya memiliki sikap positif terhadap teman sebaya yang mulai berkembang. Hal ini ditunjukkan dengan munculnya sikap solider (setia kawan), karena adanya kepentingan dan kebutuhan yang sama. Simpati dan merasakan perasaan orang lain 
(empati) mulai berkembang pada usia remaja. Remaja tengah berusaha bersikap sesuai dengan kebiasaan dalam kelompoknya, dengan kata lain mereka menyesuaikan diri dengan teman-teman sebayanya (Masganti, 2012:110).

Selanjutnya siswa MA mengalami Perkembangan konsep-diri. Perkembangan konsep-diri merupakan kulminasi dari berbagai faktor yang dialami oleh siswa, baik faktor yang bersifat internal maupun faktor yang bersifat eksternal. Ketika siswa berinteraksi dengan faktor-faktor tersebut, mereka mengamati, menyerap, mengintegrasikan serta menginternalisasikan ke dalam diri mereka. Nilai-nilai yang diperoleh dari proses internalisasi mereka yakini dan dijadikan sebagai konsep-diri (Desmita, 2009: 64). Melihat pemaparan perkembangan tersebut, maka kompetensi pada level karakterisasi pada mapel Al-Qur'an Hadis ini sesuai denganperkembangan psikologi pada ranah afektif. Peserta didik pada usia MA masih kebingungan bahkan cenderung ambivalen dalam bersikap. Sehingga internalisasi nilai-nilai yang ada pada materi ke dalam diri peserta didik ini dapat membentuk suatu prinsip hidup dan dijadikan sebagai konsep diri agar emosi nya dapat di kontrol dengan baik dan pada akhirnya menunjukkan sikap yang baik pula.

\section{c) Ranah Psikomotor}

Keterampilan proses psikomotor (Yoki Ariyana,dkk,, 2018:10)merupakan keterampilan dalam melakukan pekerjaan dengan melibatkan anggota tubuh yang berkaitan dengan gerak fisik (motorik) yang terdiri dari gerakan refleks, keterampilan pada gerak dasar, perseptual, ketepatan, keterampilan kompleks, ekspresif dan interperatif. Keterampilan proses psikomotor dapat dilihat pada tabel di bawah.

Tabel 6

Prosentasi Ranah Psikomotor Al-Qur'an Hadis MA

\begin{tabular}{|l|l|l|l|l|l|l|l|}
\hline \multirow{2}{*}{ No } & \multirow{2}{*}{ Kompetensi } & \multicolumn{2}{l|}{ Kelas X } & \multicolumn{2}{l|}{ Kelas XI } & \multicolumn{2}{l|}{ Kelas XII } \\
\cline { 3 - 9 } & & Jumlah & $\%$ & Jumlah & $\%$ & Jumlah & $\%$ \\
\hline 1. & Meniru & & & & & & \\
\hline 2. & Memanipulasi & & & 5 & $50 \%$ & 8 & $50 \%$ \\
\hline 3. & Presisi & 11 & $92 \%$ & 5 & $50 \%$ & 8 & $50 \%$ \\
\hline 4. & Mengartikulasi & 1 & $8 \%$ & & & & \\
\hline 5. & Naturalisasi & & & & & & \\
\hline
\end{tabular}

Berdasarkan tabel diatas, dapat dilihat bahwa kompetensi Psikomotor mapel AlQur'an Hadis berada pada didominasi level Presisi (P3).Tuntutan pada SKL peserta didik harus mampu bertindak dan berpikir kreatif, kolaboratif, dan seterusnya ini diperjelas dengan $\mathrm{KD}$ mendemonstrasikan menyajikan, mempraktekan dan mengkomunikasikan materi-materi yang ada pada mapel Al-Qur'an Hadis Madrasah Aliyah. 
Berdasarkan perkembangan psikologi peserta didik diusia MA pada ranah psikomotorik sudah tertuju kepada persiapan-persiapan kerja, keterampilanketerampilan menulis, mengetik, menjahit dan sebagainya sangat tepat untuk mulai dikembangkan. Dalam kompetensi dasar ranah psikomotorik ini terlihat bahwa peserta didik di dorong untuk menyajikan data, mendemonstrasikan, mengkomunikasikan bahkan sampai pada menerapkan materi yang sedang dipelajari. Dan dominasi kompetensi proses psikomotor yang berada pada level presisi yaitu yang secara independen melakukan keterampilan atau menghasilkan produk dengan akurasi, proporsi, dan ketepatan.Atau dalam bahasa sehari-hari, kategori ini dinyatakan sebagai "tingkat mahir" (Desmita, 2009: 64) hal tersebut sesuai dengan perkembangan psikologi pada usia MA. Pada kompetensi penyajian misalnya, maka dalam proses penyajian materi ini tentu melibatkan keterampilan berpikir,dan keterampilan menulis. Pada tahap mendemonstrasikan, tentu dalam hal ini melatih kemempuan peserta didik dalam kemampuan berbicara dan berbahasa,dan lain sebagainya.

\subsection{Analisis Materi Kurikulum Al-Qur'an Hadis Madrasah Aliyah}

\section{a) Konsep Sosial Profetik Kuntowijoyo}

Ilmu sosial profetik merupakan hasil analisis dan perenungan Kuntowijoyo terhadap Q.S Ali Imran [3]: 110, yang berbunyi 'kuntum khaira ummatin ukhrijat linnasi ta'muruna bil ma'rufi wa tanhauna 'anil munkari wa tu'minuna billahi' yang artinya "Engkau merupakan ummat terbaik yang diturunkan/dilahirkan di tengahtengah manusia untukmemerintah kepada yang ma'ruf dan menghindari kemunkaranserta beriman kepada Allah".

Kuntowijoyo mengemukakan empat hal yang terkandung di dalam ayat tersebut : pertama, konsep umat Islam menjadi umat terbaik (khaira ummah) dengan syarat mampu mengerjakan tiga hal berikutnya sebagai kelanjutan ayat tersebut. Artinya yaitu, umat Islam tidak secara otomatis menjadi the choosen people. Konsep umat terbaik itu lebih sebagai tantangan untuk bekerja dan berusaha lebih keras tantangan pertama. Kedua, aktivisme sejarah. Bekerja di tengah-tengah manusia (ukhrijat linnasi) memiliki makna bahwa yang ideal bagi umat Islam yaitu keikutsertaannya dalam percaturan sejarah di masyarakat.Ketiga, pentingnya kesadaran. Nilai-nilai Ketuhanan (ma'ruf, munkar, iman) menjadi tumpuan aktivisme Islam, sehingga umat Islam tidak terjerembab ke dalam nilai-nilai lain yang tidak sesuai dengan ajaran Islam. Dengan kata lain kesadaran pun penting adanya untuk membedakan etika Islam dari etika agama dan kepercayaan lain. Keempat, etika profetik. Artinya ayat itu berlaku umum untuk baik individu (orang awam, petani, ahli), lembaga (universitas, ormas, orsospol) dan kolektivitas (jama'ah, kelompok masyarakat dan umat) (Kuntowijoyo, 2005).

Dalam pandangan Kuntowijoyo, hal utama ilmu sosial profetik adalah semangat emansipasi umat yang nyata dan historis dan mengkaitkannya denganpermaslahan aktual yang dihadapi umat. Menurutnya problem umat sekarang adalah bagaimana menndorong umat dalam melakukan transformasi menuju masyarakat industrial, 
civil society, ekonomi yang non eksploitatif, masyarakat demokratis, negara rasional dan budaya yang lebih manusiawi. Dan hal itu pula yang mestinya didorong adalam pendidikan Islam termasuk dalam maple Al-Quran Hadis.

Secara spesifik menurut M. Fahmi (2005:117) Kuntowijoyo tidak memberikan pengertian tentang pendidikan profetik itu sendiri. Namun Kuntowijoyo mengambil kata profetik tersebut kemudian dimasukkan kedalam penemuannya yaitu Ilmu-ilmu Sosial Profetik, ilmu-ilmu sosial berdasarkan empat konsep yang di atas mengandug tiga muatan nilai yaitu humanisme (Amar ma'ruf) dalam arti memanusiakan manusia dengan terus menggali potensi baik dalam diri manusia. Liberasi (nahi munkar) dalam arti melarang pada hal-hal yang mengakibatkan terjadinya kejahatan dan kerusakan, dan oleh Kuntowijoyo ditafsirkan membebaskan manusia dari kekejaman kemiskinan, pemerasan kelimpahan, dominasi struktur yang menindas dan hegemoni kesadaran palsu. Terakhir adalah transendensi Transendensi merupakan unsur terpenting dari ajaran sosial Islam yang terkandung dalam Ilmu Sosial Profetik dan sekaligus menjadi dasar dari dua unsur lainnya; humanisasi dan liberasi. Oleh karena itu, ketiga unsur (pilar) tersebut tidak dapat dipisahkan satu sama lain. Yang dimaksud dengan transendensi dalam pembahasan ini adalah konsep yang diderivasikan dari tu'minuna bi Allah (beriman kepada Allah), atau bisa juga istilah dalam teologi (misalnya persoalan Ketuhanan, mahluk-mahluk gaib). Kemudian unsur-unsur tersebut dikolaborasikan dengan sifat-sifat kenabian (profetik) yakni sidiq, amanah, tablig dan fatonah. Tiga muatan itulah yang mengkarakteristikkan adanya pendidikan profetik dengan berdasarkankan Al-Qur'an surat Ali Imron ayat 110.

\section{b) Analisis Materi Kurikulum Al-Qur'an Hadis Madrasah Aliyah berbasis Sosial Profetik}

Sebagaimana telah dikemukakan sebelumnya, bahwa ruang lingkup materi AlQur'an Hadis MA terbagi menjadi 3, yaitu :

a. Masalah dasar-dasar ilmu al-Qur'an meliputi: Al- Qur'an dan wahyu menurut para ulama', sejarah penurunan dan penulisan Al-Qur'an, bukti-bukti keautentikan Al-Qur'an, kemukjizatan Al-Qur'an, pokok-pokok isi Al-Qur'an, struktur ayat dan surat dalam Al-Qur'an.

b. Dasar-dasar ilmu al-hadits meliputi: perihal hadis, sunah, khabar dan atsar (macam-macam sunnah), perkembangan hadis, unsur-unsur hadis, fungsi hadis terhadap Al-Qur'an, pembagian hadis dari segi kuantitas dan pembagian hadis dari segi kualitasnya, biografi tokoh-tokoh hadis dan kitabnya.

c. Tema-tema yang ditinjau dari perspektif al-Qur'an dan Hadis, yaitu: Manusia dan tugasnya sebagai khalifah di bumi, demokrasi dan musyawarah mufakat, Keikhlasan dalam beribadah, Nikmat Allah dan cara mensyukurinya, Perintah menjaga kelestarian lingkungan hidup, pola hidup sederhana dan perintah menyantuni para dhuafa, berkompetisi dalam kebaikan, Amar ma'ruf nahi munkar, ujian dan cobaan manusia, tanggung jawab manusia terhadap keluarga dan masyarakat, Berlaku adil dan jujur, toleransi dan etika pergaulan, etos kerja, makanan yang halal dan baik, Ilmu pengetahuan dan teknologi. 
Menurut penulis materi-materi yang ada pada kurikulum Al-Qur'an Hadis di MA ada yang sudah sesuai ada pula yang belum sesuai jika dilihat dari perspektif social profetik Kuntowijoyo. Misalnya, materi pada jenjang kelas X materi dasar-dasar ilmu Al-Qur'an dan Hadis ini menurut penulis sudah sesuai. Usia peserta didik tingkatan Aliyah (Latifah Nur Ahyani, 2018:89) memiliki sikap kritis terhadapa ajaran agama. Dalam tahap ini peserta didik mulai mendiskusikan topik-topik agama bersama teman sebaya. Terkadang remaja lebih melihat segi praktis dan realita dari ajaran agama. Mereka membandingkan antara apa yang ideal (secara teori) dengan apa yang tampak nyata, sehingga apa yang dahulu dipercayainya sebagai hal yang benar, pada masa remaja mulai diragukan. Misalnya, para remaja awal sering mempertanyakan tentang dosa dan neraka, pahala dan surga, karena hal-hal ini bersifat abstrak. Mereka juga meragukan doa mereka ketika doa tersebut tidak terkabul. Akibatnya, minat terhadap agama dapat melemah dan praktek keagamaan (ibadah) sering ditinggalkan.

Adanya materi mengenai dasar-dasar ilmu Al-Quran dan Hadits di jenjang kelas X dengan kompetensi proses kognitif dominan pada level mengnalisis (C4) ini dapat membantu peserta didik dalam menghadapi keraguannya terhadap agama yang banyak memberikan ajaran bersifat abstrak, sehingga diharapkan materi dasar-dasar ilmu Al-Qur'an dan Hadis ini mampu mendorong tumbuhnya kesadaran peserta didik akan adanya kebenaran Al-Qur'an Hadis dan pentingnya patuh terhadap perintah Allah, perintah agama yang bersumber dari Al-Qur'an dan Hadis tersebut. Materi tersebut mengandung unsur transendensi pada konsep social profetik Kuntowijoyo.

Namun, berdasarkan penelitian Allport (Jalaludin, 2016)yang menyimpulkan bahwa agama yang ajarannya bersifat lebih konservatif lebih banyak berpengaruh bagi para remaja untuk tetap taat pada ajaran agamanya, sementara agama yang kurang konservatif dan cenderung liberal mudah untuk merangsang penganutnya sehingga banyak meninggalkan ajaran agamanya.

Konservativisme agama, dalam hal ini Islam hari ini menjadi hal yang menumbuhkan optimisme sekaligus kecemasan menurut penulis. Karena, memang banyak diyakini bahwa ibadah ritual ini merupakan sumber kebajikan yang akan menumbuhkan kesabaran dan kepekaan sosial dan keinginan berbuat baik kepada sesame manusia. Di sisi lain, konservatifisme dalam agama juga menimbulkan kecemasan, karena konservatifisme agama diyakini sebagai pintu menuju intoleransi dan radikalisme. Sehingga materi dasar-dasar Al-Qur'an dan Hadis yang meliputi pengertian Al-Qur'an dan hadis dari berbagai ulama, sejarah penurunan dan penulisn Al-Qur'an dan hadis, bukti-bukti keontetikan Al-Quran dan lain sebagainya dapat mendorong peserta didik untuk memahami bagaimana perbedaan memahami bahwa agama itu sangat beragam sehingga peserta didik mampu memahami keberagaman tersebut. dan hal tersebut tentunya untuk mengikis sikap konserfativisme yang akan menimbulkan sikap radikalisme. Hal ini sejalan pula dengan landasan sosiologis pengembangan kurikulum di Madrasah yang bertujuan 
mewujudkan madrasah sebagai agent of change (agen perubahan) dan social reconstruction (rekonstruksi sosial) untuk menyiapkan peserta didik yang memiliki sikap moderasi keberagamaan dan berkontribusi secara optimal dalam upaya membangun knowledge-basedsociety (masyarakat berbasis pengetahuan) dalam bingkai Negara Kesatuan Republik Indonesia (KMA, 2019:13). Sementara materi pokok-pokok isi Al-Quran, kemukjizatan Al-Quran dan sebagainya mendorong peserta didik agar dapat meyakini benar bagaimana sumber ajaran agama Islam ini begitu otentik dan valid kebenarannya.

Selanjutnya, materi lain yang menurut penulis relevan dengan konsep social profetik Kuntowijoyo dan mengandung unsur liberasi adalah materi mengenai perintah untuk menjaga kelestarian lingkungan hidup. Materi ini menurut penulis akan lebih baik jika disampaikan dengan keterkaitan pada kebijakan pembangunan berkelanjutan (sustainable development) yang berwawasan lingkungan di Indonesia. Karena pembangunan merupakan keniscayaan di setiap negara. Sejatinya proses pembangunan itu merupakan proses perubahan menuju hal yang lebih baik. namun proses pembangunan di Indonesia seringkali tidak mempertimbangkan aspek lingkungan, padahal tidak dapat dipungkiri bahwa pembangunan ini memiliki hubungan yang erat dengan lingkungan (Rosana, 2018). Belum lagi jika berbicara revolusi industry 4.0 yang mendorong pembangunan industry di mana-mana, dan sama-sama diketahui bahwa dampak pembangaunan industri ini akan menimbulkan banyak bencana alam jika tidak mempertimbangkan aspek lingkungan.

Selain itu, perspektif sosial profetik Kuntowijoyo yang mengatakan Islam sangat berkepentingan pada realitas sosial bukan hanya untuk dipahami tetapi juga untuk diubah dan dikendalikan. Kelahiran konsep sosial profetik juga berdasarkan pada perubahan paradigma, yakni sebuah gerakan yang mengajak umat Islam untuk menjadikan Al-Quran sebagai teori-teori ilmu, agar dapat lebih bersifat aplikatif. Pendidikan Agama Islam berbasis sosial profetik yang dicetuskan oleh Kuntowijoyo ini dapat dijadikan alternatif pengembangan bagi pendidikan Islam yang lebih baik. Menurut Kuntowijoyo, secara keseluruhan, ketiga nilai ilmu sosial profetik (humanisasi, liberasi dan transendensi) akan menjadi satu kesatuan gerakan aktivisme sejarah untuk mencapai khaira ummah. Karena itu, penerapan ketiganya di harapkan akan melahirkan peserta didik pada tingkat khaira ummaty pula (Kuntowijoyo dan A. E Priyono, 2008:229).

Pada dasarnya pendidikan adalah permasalahan kemanusiaan, maka sebagai sasaran bidik yang pertama adalah manusia (antropologi). Pendidikan yang berwawasan kemanusiaan dalam memiliki pengertian bahwa pendidikan harus memandang manusia sebagai subjek pendidikan bukan sebaliknya. Oleh karena itu starting point dari proses pendidikan berawal dari pemahaman teologis-filosofis tentang manusia, yang pada akhirnya manusia diperkenalkan keberadaan dirinya sebagai khalifah Allah di muka bumi. Jika pendidikan lepas dari dasar-dasar ini, maka pada akhirnya pendidikan hanya akan melahirkan tata cara hidup yang tidak lagi konstruktif bagi tegaknya nilai-nilai kemanusiaan. Oleh karena humanisasi adalah proses manusia 
untuk memanusiakan manusia, sebagaimana juga pendidikan, maka ia harus mulai dari suatu proses yang dialogis dengan melibatkan kesadaran kritis. Dan materi mengenai Manusia dan tugasnya sebagai Khalifah Fil ard' mengandung unsur humanisasi serta sesuai dengan konsep social profetik Kuntowijoyo.

Adapun materi-materi lain seperti demokrasi dan musyawarah mufakat, Keikhlasan dalam beribadah, Nikmat Allah dan cara mensyukurinya, pola hidup sederhana dan perintah menyantuni para dhuafa, berkompetisi dalam kebaikan, Amar ma'ruf nahi munkar, ujian dan cobaan manusia, tanggung jawab manusia terhadap keluarga dan masyarakat, Berlaku adil dan jujur, toleransi dan etika pergaulan, makanan yang halal dan baik, menurut penulis materi-materi tersebut dapat dirangkum dalam satu atau dua materi yang didalamnya mencakup materi-materi tersebut. Misalnya, materi toleransi dan etika pergaulan, didalamnya dapat dicantumkan bagaimana demokrasi, musyawarah dan mufakat, dapat juga memuat tanggung jawab terhadap keluarga, masyarakat dan lainnya.

Penulis telisik kembali kesesuaian materi dengan SKL dan KI tepatnya pada poin "seni, budaya, dan humaniora dengan wawasan kemanusiaan, kebangsaan, kenegaraan" , maka materi budaya, dan wawasan kebangsaan dalam materi tematema perspektif Al-Qur'an Hadis ini belum tercantum di dalamnya. Materi budaya lokal dan kebangasaan dalam perspektif Al-Qur'an Hadis menurut penulis penting untuk dimasukan dalam kurikulum guna menangkal paham radikalisme di Indonesia. Hal ini mengingat banyaknya penelitian yang menunjukkan paham radikalisme marak terjadi pada peserta didik usia SMA dan Madrasah Aliyah. Salah satunya yaitu penelitian yang dilakukan oleh Dirana Sofiah dan kawan-kawan pada tahun 2017 yang dalam kesimpulannya menyatakan sebanyak $75 \%$ pengurus rohis di salah satu SMA di Jakarta berpandangan radikal (Dirana Sofiah,dkk, 2017 ).

Dalam konteks mata pelajaran Quran-Hadis pada Madrasah Aliyah, pendidik mata pelajaran ini selain pendidik yang secara keilmuan memahami alQuran dan Hadis secara komprehensif, mampu menggali nilai-nilai inti yang terkandung dalam dua sumber tersebut, juga dituntut agar memahami kebutuhan dasar peserta didik di madrasah secara jelas. Pendidik mengetahui segala hal ihwal psikologis peserta didik sebagai individu dan kelompok dimana pendidik hendak menciptakan pengalaman belajar bersama peserta didik. Sehingga output dari pembelajaran materi-materi Al-Quran hadis ini benar-benar dapat dirasakan dann dilakukan oleh peserta didik sebagaimana harapan besar umat islam terhadap pendidikan Islam.

\section{Kesimpulan}

Dari hasil telaah kurikulum mata pelajaran Al-Qur'an Hadis di Madrasah Aliyah, penulis menemukan bahwa :

1. Telaah kompetensi berdasarkan tingkat kemampuan berfikir tinggi pada aspek kompetensi afektif spirirtual (KI-1) berada pada tahap Karakterisasi (A5) sebanyak 90\%, kompetensi afektif social (KI-2) berada pada level karakterisasi dengan prosentasi $100 \%$, kompetensi kognitif nya (KI-3) berada pada level 
menganalisis (C4) dengan total prosentase 97\%, dan kompetensi psikomotor (KI-4) 63\% dan banyak yang sudah sesuai dengan psikologi perkembangan pada usia MA. Namun, pada ranah kognitif terdapat ketidaksesuaian antara SKL dan KI yang berdampak pada KD dan tentunya berdampak pula pada output dari pembelajaran Al-Quran Hadis. Ketidaksesuaian ini tepatnya terdapat pada poin pengetahuan metakognitif yang berfungsi untuk menumbuhkan kesadaran dan kewaspadaaan dalam diri peserta didik, menurut penulis pengetahuan metakognitif ini dapat terpenuhi dengan baik jika proses kompetensi kognitif di imbangi dengan level kompetensi mengevaluasi (C5) dari KD yang sudah ada yaitu yang dominan di level Menganalisis (C4).

2. Telaah materi berdasarkan perspektif social profetik Kuntowijoyo maka didapatkan bahwa materi dasar-dasar al-Qur'an Hadis sesuai dengan konsep Kuntowijoyo.Begitupun dengan materi perintah menjaga kelestarian lingkungan hidup dan tugas manusia sebagai khalifah Fil ard menurut penulis sesuai dengan konsep social Profetik. Namun telaah kesesuaian materi dengan SKL dan KI tepatnya pada poin "seni, budaya, dan humaniora dengan wawasan kemanusiaan, kebangsaan, kenegaraan" masih terdapat ketidak sesuaian karena tidak ada materi mengenai budaya dan kebangsaan. Maka materi budaya, dan wawasan kebangsaan dalam materi tema-tema perspektif Al-Qur'an Hadis ini belum tercantum di dalamnya.

\section{Saran}

Materi budaya lokal dan kebangasaan dalam perspektif Al-Qur'an Hadis menurut penulis penting untuk dimasukan dalam kurikulum untuk menangkal paham radikalisme di Indonesia. Hal ini mengingat banyaknya penelitian yang menunjukkan paham radikalisme marak terpapar pada peserta didik usia SMA dan Madrasah Aliyah. Hal ini mengingat banyaknya penelitian yang menunjukkan paham radikalisme marak terpapar pada peserta didik usia SMA dan Madrasah Aliyah. Salah satunya penelitian yang dilakukan oleh Dirana Sofiah dan kawankawan pada tahun 2017 yang dalam kesimpulannya menyatakan sebanyak $75 \%$ pengurus rohis di salah satu SMA di Jakarta berpandangan radikal.

Selain itu, sebaiknya materi-materi seperti demokrasi dan musyawarah mufakat, Keikhlasan dalam beribadah, Nikmat Allah dan cara mensyukurinya, pola hidup sederhana dan perintah menyantuni para dhuafa, berkompetisi dalam kebaikan, Amar ma'ruf nahi munkar, ujian dan cobaan manusia, tanggung jawab manusia terhadap keluarga dan masyarakat, Berlaku adil dan jujur, toleransi dan etika pergaulan, makanan yang halal dan baik, menurut penulis materi-materi tersebut dapat dirangkum dalam satu atau dua materi yang didalamnya mencakup materimateri tersebut. Misalnya, materi toleransi dan etika pergaulan, didalamnya dapat dicantumkan bagaimana demokrasi, musyawarah dan mufakat, dapat juga memuat tanggung jawab terhadap keluarga dan masyarakat dan lainnya. 


\section{Daftar Pustaka}

Anderson, L W. 2010. Pembelajaran, Pengajaran, dan Asesmen. Yogyakarta: Pustaka Pelajar.

Ariyana, Yoki.dkk. 2018. Pembelajaran Berorientasi Kemampuan Berfikir Tinggi. Jakarta: Kemendikbud.

Desmita. 2009. Psikologi Perkembangan Peserta Didik. Bandung: Rosdakarya

Direktorat Pendidikan Madrasah Direktorat Jenderal PendidikanIslam, Peraturan Menteri Agama RI Nomor 2 Tahun 2008.

Fahmi, M. 2005. Islam transendental: Menelusuri Jejak-Jejak pemikiran islam Kuntowijoyo. Yogyakarta: Pilar Religia.

Ibda, Fatimah. 2015. Perkembangan Kognitif : Teori Jean Piaget, INTELEKTUALITA - Volume 3, Nomor 1.

Jalaludin. 2016. Psikologi Agama. Jakarta: RajaGrapindo.

Keputusan Menteri Agama (KMA) Nomor 183 Tahun 2019 tentang Kurikulum PAI dan Bahasa Arab Pada Madrasah.

Kuntowijoyo. 2005. "Maklumat Sastra Profetik" dalam Horison.

Kuntowijoyo. 2001. Muslim tanpa Masjid.Bandung: Mizan.

Kuntowijoyo, A. E Priyono. 2008. Paradigma Islam Interpretasi Untuk Aksi .Bandung: Mizan.

Masganti. 2012. Perkembangan Peserta Didik. Medan: Perdana Publishing.

Mulyasa, E. 2014. Pengembangan dan Implementasi Kurikulum 2013. Bandung: PT Remaja Rosdakarya.

Nur Ahyani, Latifah. Dkk. 2018. Buku Ajar Psikologi Perkembangan Anak dan Remaja.Kudus: Univ.Muria Kudus.

Peraturan Menteri Pendidikan dan Kebudayaan No. 54 Tahun 2013 Tentang Standar Kompetensi Lulusan Pendidikan Dasar dan Menengah.

Rosana, Mira. 2018. Kebijakan Pembangunan Berkelanjutan yang Berwawasan Lingkungan di Indonesia. KELOLA: Jurnal Ilmu Sosial, Vol 1 No.1.

Samiudin. 2017. Pentingnya Memahami Perkembangan Anak Untuk Menyesuaikan Cara Mengajar Yang Diberikan, PANCAWAHANA: Jurnal Studi Islam, Vol.12, No.1

Sofiah, Dirana, dkk, Pandangan Anggota Rohis SMA Tentang Radikalisme Agama, Jurnal Studi Al-Qur'an; Membangun Tradisi Berfikir Qur'ani, Vol. 13, No. 1 , 2017.

Wulandari, Yeni. 2017.Skripisi: "Implementasi Metode Pembelajaran Pada Mata Pelajaran Al-Quran Hadis di MAN 1 Tulungagung”. Tulungagung: IAIN Tulungagung.

Yusuf, Syamsul. 2017. Perkembangan Psikologi Anak dan Remaja. Bandung: Rosda Karya. 